\title{
Legal Constraints on the Indeterminate Control of 'Dangerous' Sex Offenders in the Community: The French Perspective
}

\author{
Martine Herzog-Evans*
}

\begin{abstract}
France literally 'discovered' sexual abuse following neighbour Belgium's Dutroux case in the late 1990s. Since then, sex offenders have been the focus of politicians, media and law-makers' attention. Further law reforms have aimed at imposing mandatory supervision and treatment, and in rare cases, preventive detention. The legal framework for mandatory supervision and detention is rather complex, ranging from a mixed sentence (custodial and mandatory supervision and treatment upon release or as a stand-alone sentence) to so-called 'safety measures', which supposedly do not aim at punishing an offence, but at protecting society. The difference between the concepts of sentences and safety measures is nevertheless rather blurry. In practice, however, courts have used safety measures quite sparingly and have preferred mandatory supervision as attached to a sentence, notably because it is compatible with cardinal legal principles. Procedural constraints have also contributed to this limited use. Moreover, the type of supervision and treatment that can thus be imposed is virtually identical to that of ordinary probation. It is, however, noteworthy that a higher number of offenders with mental health issues who are deemed 'dangerous' are placed in special psychiatric units, something that has not drawn much attention on the part of human rights lawyers.
\end{abstract}

Keywords: Preventive detention, mandatory supervision, sex offenders, retrospective penal laws, legality principle

\section{Introduction}

\subsection{A Late Onset}

It was essentially with the Dutroux case in neighbouring Belgium that France suddenly discovered the issue of sex offences against children, which it had previously ignored - just as it only criminalised rape in $1980 .{ }^{1}$ The press thus played an important role in drawing attention

Martine H-Evans, PhD, is a Professor at the Department of Law, Universite de Reims Champagne-Ardenne. This article is part of a comparative research project involving several European jurisdictions, of which the results are presented in this special issue. For further background of the theme and outline of the issue and individual articles, as well as the comparative analysis, see the contribution by Van der Wolf in this issue.

1. Prior to 1980 , rape was a felony. to a type of offence that its patriarchal culture had preferred to ignore. France, however, does not have a widely read populist press, in contrast with, for instance, England and Wales. Therefore, in addition to describing events that have occurred or court hearings that deal with high-profile sex offenders, it also tends to raise deeper questions, such as why sex offenders tend to commit new crimes and whether treatment works although it tends to ignore science in doing so. Nonetheless, as in many other jurisdictions, when a sex offender who has been released on parole (libération conditionnelle) reoffends quite dramatically, the media raises questions as to why he was released in the first place and tends to cast blame on a system that allows such a thing to happen and, in some cases, onto those who made the decision or those who assessed him/her as being low risk. For instance, in a recent case in which the offender, a psychopath with twenty prior convictions and numerous violations of previous community sentences and measures, sexually abused and battered two young women, one of whom nearly died, the press pointed to the fact that he was on 'semi-freedom' (semi-libertê), a measure whereby the offender has to spend nights in prison, but can circulate in the community during the day. $^{2}$

\subsection{Sex Offending and Politics}

Inevitably, then, the press - and, even more so, the widely watched 8 O'clock evening news - is an essential piece of the equation when it comes to understanding French sex offences law. For indeed, virtually every single piece of legislation that has been enacted over the past two decades has reacted to a 'fait divers' (high-profile crime), and this has been true whether the extant government was punitive ('the right') or more lenient ('the left'). In 1994, a 'true life' (perpétuité réelle) sentence was created following the death of a child by a paedophile; in 1998, the 'socio-judicial supervision' (suivi socio-judiciaire - SSJ) Act enacted by the socialist government directly followed the Dutroux case. By the time Nicolas Sarkozy became the Minister of the Interior (2002-2007) and then the President (2007-2012), the media's attention had fully switched to sex offenders, and in particular, recidivists. During a ten-year legislative frenzy, Nicolas Sarkozy enacted no less than twelve

2. Le Parisien, 11 août 2015 
criminal law Acts, several of which focused, inter alia, on sex offenders $\left(2005,2007,2008,2010,2012\right.$ Acts $\left.^{3}\right)$. Each time, he reacted to yet another high-profile case. For instance, the 2012 Act was passed following the Meilhon case, ${ }^{4}$ in which a repeat offender who had sexually assaulted his co-inmate - information that was not communicated by the prison-based probation service to its community-based fellow agency - abducted a young girl after his release, whom he raped and assassinated. The media's attention focused on the licence he was given following his release: no supervision whatsoever had been put in place because of the local probation services' extreme workload (200 cases per probation officer).

Every single point of Mr Sarkozy's laws was fiercely criticised by the left opposition, in particular, those imposing various forms of mandatory supervision or detention (mesures de sûreté: 'safety measures') on sex offenders upon their release. Yet, the current socialist government's former Minister of Justice, Ms Taubira, did not abrogate a single point of them, and quite the contrary, added one more 'safety measure' to the legal system, focusing on offenders who had been declared partially irresponsible by reason of insanity, some of whom, though not all, were sex offenders. Currently, the media's and politicians' attention are no longer on sex offenders, and high-profile cases do not draw as much attention as they did, as the main focus is now on terrorists - as it was in the mid-1990s during the series of attacks on France

Sex offenders - along with recidivists, with whom they were often confused - were thus seen as national public enemies from 1998 to the major Paris Charlie Hebdo attack of January 2015. The legal heritage of those years, as well as its rationale, has been left untouched.

What is clear then is that France mostly deals with such issues in a purely political and 'communicative' (to the media and the public) fashion; evidence and science play little part in such debates nor in the legislations that are enacted.

\subsection{A Focus on Treatment}

The 1998 Act fairly balanced punitive and treatment/ rehabilitative goals. ${ }^{5}$ Although the Dutroux case did precipitate action, mandatory supervision and treatment for sex offenders had been 'in the air' since the aforementioned 1994 reform, and they had been advocated

3. Loi no. 2005-1549, 12 December 2005; Loi no. 2007-1198, 10 August 2007; Loi no. 2008-174 25 February 2008; Loi no. 2010-242 10 March 2010; Loi no. 2012-409 27 March 2012.

4. Inspection des services pénitentiaires, Rapport relatif aux conditions de prise en charge de M. Tony Meilhon par le SPIP de Loire-Atlantique, 10 février (2011). Inspection judiciaire, Inspection de fonctionnement du service de l'application des peines du tribunal de grande instance de Nantes, Février, No. 13/2011 (2011)

5. J. Castaignède, ‘Le suivi socio-judiciaire applicable aux délinquants sexuels ou la dialectique sanction-traitement', Recueil Dalloz 23 (1999); P. Salvage, 'Les soins obligatoires en matière pénale', JCP ed. G., I, 4062 (1997); J. Castaignède, 'La prise en charge des abuseurs sexuels par le droit pénal', in R. Cario and J.-C. Heraut (eds.), Les abuseurs sexuels: quel(s) traitement(s)? (1998) 19 by various commissions ${ }^{6}$ and specialists. ${ }^{7}$ In a rare case of bipartisan agreement, the 1998 Act was submitted to Parliament by the right-wing Minister of Justice Michel Toubon, and it was his socialist successor, Elisabeth Badinter, who obtained its enactment in 1998, after new elections had interrupted her colleague's initial attempt. A similar lack of dispute marked the creation of the new safety measure by Ms Taubira in 2014. In both cases, this was because both legislations mostly consisted in imposing treatment, something over which there was strong political consensus.

Conversely, the entire Sarkozy era was plagued with argumentative debates and disputes, probably because the conservative politician's stance was perceived as being excessively punitive ${ }^{8}-$ even though the treatment component was still at the forefront, ${ }^{9}$ as many of the influencing commissions of the time reveal. ${ }^{10}$ It did not help because such reforms took place against the backdrop of other very punitive penal reforms. ${ }^{11}$ Many critics have also complained about his frantic legislative production, which vastly transformed 'sentence implementation' law (droit de l'exécution des peines) to the point that this legal field has become one of the most uselessly complex of all. Each law consisted in refined bifurcations and possibilities aimed at restricting parole and coercing sex offenders into treatment whilst they were in prison and after their release (for a simplified overview, see Table 1 on pages 72-73).

More recently, criticism has furthermore focused on the lack of human and financial resources in both the justice and health sectors, and on the lack of evidence-based support for the assessment and treatment of sex offend-

6. T. Lemperière, Rapport de la commission d'étude sur l'évaluation et I'expertise psychiatrique des condamnés (1997); C. Balier, C. Parayre \& C. Parpillon, 'Traitements des auteurs de délits et crimes sexuels. Conclusions et recommandations du groupe de travail', Forensic 13 (1996).

7. D. Sagury, 'Des soins pour les délinquants sexuels', Le Monde 15-16 December, at 15 (1996).

8. M. Herzog-Evans, 'Récidive: surveiller et punir plus plutôt que prévenir et guérir', AJ Pénal 305 (2005).

9. J.-L. Senon and C. Manera, 'L'obligation de soins dans la loi renforçant la lutte contre la récidive', AJ Pénal 367 (2007).

10. And notably: J.-P. Garraud, Rapport sur le Mission Parlementaire confiée par le Premier Ministre à Monsieur Jean-Paul Garraud, député de la Gironde, sur la Dangerosité et la prise en charge des individus dangereux, Ministère de la Justice et Ministère de la santé et des solidarités (2006); E. Blanc, Rapport d'information sur le suivi des auteurs d'infractions à caractère sexuel, en conclusion des travaux d'une mission d'information relative à l'exécution des décisions de justice, presided by M.J.-L. Warsmann, 29 February, National Assembly, No. 4421 (2012); E. Milgrom, P. Bouchard \& J.P. Olié, 'La prévention médicale de la récidive chez les délinquants sexuels', 194 Bulletin de l'Académie nationale de médecine 1033 (2010).

11. J. Danet, Justice pénale, le tournant, Paris, Le Monde Actuel, Folio (2006); V. Gautron, 'De la société de surveillance à la rétention de sûreté. Etapes, faux semblants, impasses et fuites en avant', AJ Pénal 54 (2009); M. Herzog-Evans, 'French Post Custody Law (2000-2009): From Equitable Trial to the Religion of Control', 1 European Journal of Probation 97 (2009). 
ers, ${ }^{12}$ which has rendered the reforming logorrhoea of the past two decades largely useless.

With the exception of the 1998 Act, which had reformed the health and criminal laws equally, the changes adopted thereafter essentially delegated the definition of the legal framework to criminal law. That said, nothing could be done without the contribution of health services, which were increasingly mandated by penal courts to assess and care for sex offenders. It is also important to understand that, parallel to the mandatory treatment imposed under criminal law, France also detains offenders under the umbrella of mental health law. Sex offenders who are diagnosed with a serious mental health condition or who are currently deteriorating can naturally be transferred to psychiatric wards for treatment under ordinary health law regulations. The most dangerous of them can also be detained in special psychiatric structures (Unités pour Malades Difficiles - UMD - Serious Patient Units) regulated essentially by the Health Code, which was amended in $2011 .{ }^{13}$ Sex offenders can thus be detained under this more discreet regime, very few political or academic debates have addressed it.

\subsection{Three Different Reforming Era}

Focusing essentially on criminal law rules, one can distinguish three different eras. ${ }^{14}$ The 1998 reform consisted in creating a new sentence, which, at the time, was lawful in view of the general legal framework and principles. This sentence, SSJ, consists in mandatory treatment and supervision and is either a stand-alone community sentence or a post-custodial supervision sentence. In many ways, with the exception of the legal framework for treatment (see 2.6), this is, in fact, not dissimilar to a regular probation sentence or a custodial sentence combined with a probation licence upon release.

During Nicolas Sarkozy's governance, on the other hand, many criminal law principles were violated. The principle of legality was thus attacked when a 2007 Act imposed mandatory treatment for people who could have been liable to SSJ, but had not been thus sentenced. The principles of legality, safety and perhaps proportionality were also weakened when two laws $(2005,2008)$ created a total of four 'safety' measures (judicial safety surveillance of dangerous offenders SJPD; GPS-electronic monitoring - PSEM; safety surveillance $-\mathrm{SS}$; safety detention $-\mathrm{RS}^{15}$ ) that are restric-

12. M. Herzog-Evans, 'Outils d'évaluation: sortir des fantasmes et de l'aveuglément idéologique', AJ Pénal février 75 (2012) and our consultation to the Parliament, available at: <http://herzog-evans.com/ observations-ecrites-concernant-le-projet-de-loi-de-programmationrelative-a-lexecution-des-peines/> (last visited 27 May 2016)

13. E. Péchillon 'Censure partielle de la loi du 5 juillet 2011 relative aux soins sous contrainte: vers une réforme en profondeur de la psychiatrie avant octobre 2013? Note sous Conseil constitutionnel, décision no. 2012-235 QPC du 20 avril 2012, Association de réflexion et de proposition d'actions sur la psychiatrie', 26 JCP Adm. 2230 (2012).

14. For a detailed presentation, see M. Herzog-Evans, Droit de l'exécution des peines (2016).

15. SJPD: Surveillance judiciaire des personnes dangereuses; PSEM: Placement sous surveillance électronique mobile; SS: Surveillance de sûreté; RS: Rétention de sûreté. tive or custodial measures imposed without a new offence having been committed: they allow for the longterm post-custodial supervision of sex and other violent offenders and considerably extend the cases where release must be preceded by risk assessment - risk assessment that, as we shall see, is outdated and unreliable. Parallel to this, Nicolas Sarkozy also made it much more difficult for sex offenders, recidivists and people serving long prison sentences to obtain an early release. Ms Taubira's 2014 law reform, for her part, broke with tradition by creating her own safety measure, whilst dispensing with the solid procedural safeguards that her predecessor had put into place to compensate for the substantial law violations inherent in such safety measures.

In practice, $\mathrm{SSJ}$ is used more frequently than any of the other tools, as courts patently favour measures that are compatible with essential criminal law principles. That being said, most sex offenders are, in practice, submitted to ordinary sentences and measures, such as probation orders and custodial sentences, both of which can include a treatment obligation.

There are currently no proposals for the extension of safety measures. However, the opposition is already adopting its usual 'tough on crime' rhetoric in the media, prior to the upcoming regional (December 2015) and presidential elections (2017), and it is highly likely that the current legal arsenal will be extended if the opposition wins the election. In view of the recent terrorist attacks on France in 2015, it is likely that such changes will not focus on sex offenders.

It is impossible to list all of the specific regulations and constraints to which sex offenders are submitted. Therefore, focus will be on SSJ and the five existing safety measures hereafter.

\section{Legal Frameworks for SSJ and Safety Measures}

\subsection{Pre-Legislative Justification}

The justifications presented for SSJ and safety measures have always represented a balance between three different and somewhat opposing objectives: neutralisation, rehabilitation and treatment. Whether from the left or the right, politicians have justified every single point of these measures by referring to these goals. Indeed, the right places a little more emphasis on safety, whilst the left places more emphasis on rehabilitation. However, they have had a similar focus on treatment. Their discourse, identically, has thus been that all sex offenders and some violent offenders need treatment and supervision when they are released; those committing the more serious of these offences need, in addition to treatment and supervision, some form of containment, be it via GPS-EM or custody. Amongst specialists and academics, there has not been much opposition to the rehabilitative and treatment dimensions of these sentences and 
measures. The public debate has essentially focused on safety detention. The media and politicians (left opposition) have mostly criticised the assault on the general law principles embodied by safety detention, but have mostly ignored the mandatory forms of supervision, which unfortunately has allowed the latter, particularly SJPD, to prosper, in spite of the commission of similar violations and of the considerable increase in their scope.

\subsection{Target Group}

Initially, the exclusive target group for SSJ was sex offenders. Gradually, rather serious violent offences were added, including some forms of domestic violence and arson. Although, in practice, the list of offences has increased, and its original scope has become a bit more blurry, this sentence still essentially targets serious violent and sexual offences. ${ }^{16}$ The target groups for judicial surveillance and PSEM are identical because the person must be liable to SSJ for these measures to apply.

Safety detention and supervision are, so far, limited to a very restricted list of extremely serious offences (Art. 706-53-13 of the Penal Criminal Code (PPC)), namely: murder or premeditated murder, torture and barbarous acts, rape; abduction and sequestration when committed against a minor; and aggravated forms of murder or premeditated murder, torture and barbarous acts, rape, abduction and sequestration when committed against an adult.

\subsection{Definition of Risk and Danger}

Leaving aside SSJ, for which no danger criterion is imposed other than having committed a sex or violent offence for which the law states that SSJ can be pronounced, amongst safety measures, there is always a reference to either 'dangerousness' or the 'risk of recidivism', or both. Here, legislators have obviously not attempted to be clear and precise - thus adding to the violation of the principle of legality - and the level of confusion is such that it has become something of a joke amongst lawyers.

As Table 1 shows, with SJPD, a 'proven' risk of 'recidivism' is required (Art. 723-29 of the PPC). A patent dual legal difficulty arises here. First, the concept of 'recidivism' - as opposed to reoffending - has a very narrow legal definition under French law. This means that if the offender is 'lucky' enough to escape the intricacies of the concept of recidivism, ${ }^{17}$ but does reoffend, he cannot be subjected to SJPD. Secondly, because most experts are either unaware or reject evidence-based

17. Recidivism is defined as being a second offence committed after a previous one has been punished by a criminal court of law and all appeals and have been either exhausted or not used. Recidivism further requires that the second offence is committed within a specific time frame, which varies depending on the nature of the offence (misdemeanour, felony, crime). With regard to certain classes of felonies, the second offence additionally must be of an identical or a similar nature as defined by the Penal Code (Penal Code, art. 132-8 to 132-16-5 - Herzog-Evans, Récidive, Encyclopédie Pénal et Procédure Pénale, Dalloz). risk assessment tools, ${ }^{18}$ it cannot be said that the level of risk can be 'proven' according to the current scientific state of the art. As a matter of fact, in most cases, experts tend to confusingly conclude that 'one cannot exclude that $\mathrm{Mr} \mathrm{X}$ shall reoffend'. Adding to the legal uncertainty, Article 723-31 of the PPC then requires that the risk of recidivism must be established by expert testimony, stating that the person in question is 'dangerous'. In other words, the risk of recidivism has to be proven via the person's dangerousness! It is also the person's dangerousness, which is the governing criterion for PSEM (Art. 131-36-10 of the Penal Code (PC)). However, in this case, it does not have to be 'proven', but merely mentioned by experts in their written testimony.

With regard to $\mathrm{SS}$ and $\mathrm{RS}$, the confusion stems from the use of the concept of 'particular dangerousness' (Art. 706-53-13 of the PPC), which, one can attempt to guess, refers to serious risk, although, in French, 'particular' can also translate into specific. According to the PPC, this dangerousness further has to be characterised by 'a high probability of recidivism because they [the persons in question] suffer from a serious personality disorder'. In other words, it is dangerousness which is proven by a risk of recidivism (sic), rather than the other way around. Furthermore, a 'serious' personality disorder is an additional condition, which raises the following question: what distinguishes a serious personality disorder from a less serious one, and how can this adjective provide the clarity and consistency required of criminal law decisions under the cardinal principle of legality? It does not help because French psychologists and psychiatrists do not always follow international guidelines, and use their own unheard of personality disorder categorisations, the most widely used being 'perversion' ${ }^{19}$ a concept that finds its root in psychoanalysis. ${ }^{20}$
18. A. Baratta, A. Morali \& O. Halleguen, 'La dangerosité des malades mentaux bénéficiant de l'article 122-1. A propos d'une étude rétrospective portant sur 58 cas', 88 L'information psychiatrique 559 (2012). In English: M. Herzog-Evans, "“What on Earth Can This Possibly Mean?" French Reentry Courts and Experts Risk Assessment', 44 International Journal of Law and Psychiatry 98, online first: doi:10.1016/j.jilp. 2015.08.036 (2015).

19. G. Pirlot and H.L. Pedinielli, Les perversions sexuelles et narcissiques, 3rd edn (2013).

20. S. Freud, Drei Abhandlungen zur Sexualtheorie (Three Essays on the Theory of Sexuality) (1905). 
In itself, the dangerousness criterion has been nearly unanimously criticised in French legal doctrine, ${ }^{21}$ including by traditionally conservative lawyers. ${ }^{22}$ Indeed, it has been argued that this concept cannot be defined in a precise and predictable fashion, as required by the principle of legality. Although some authors have attempted to theorise this construct and have, for instance, distinguished between 'criminological dangerousness' and 'psychiatric dangerousness', ${ }^{23}$ a dichotomy widely used by psychiatrists in their testimonies, such a dichotomy has been rejected by the minority of practitioners who have adopted a more evidence-based approach. $^{24}$

One of the major issues with evaluations has also been the very possibility that risk can be assessed, with some left-leaning commentators seriously doubting it and referring to a 'Minority Report' syndrome'. ${ }^{25}$ Currently, the vast majority of experts ${ }^{26}$ and the majority of judg$\mathrm{es}^{27}$ are opposed to actuarial or other structured risk assessment tools. There also is a patent lack of a 'danger culture' amongst psychiatrists. ${ }^{28}$ This resistance is both political and theoretical: by far the dominant treatment model in France is psychoanalysis and the general population has adopted this treatment framework as if it were an absolute truth. ${ }^{29}$

Things may improve in the future, as some practitioners are obtaining training in evidence-based assessment,

21. See inter alia: P.-J. Delage, 'La dangerosité comme éclipse de l'imputabilité et de la dignité', RSC 797 (2007); P. Mbanzoulou, 'La dangerosité des détenus. Un concept flou aux conséquences bien visibles: le PSEM et la rétention de sûreté', AJ Pénal 171 (2008); P. Mbanzoulou, H. Baze, O. Razac \& J. Alvarez, Les nouvelles figures de la dangerosité (2008); G. Giudicelli-Delage, 'Droit pénal de la dangerosité - Droit pénal de l'ennemi', RSC 69 (2010); A. Coche, 'Faut-il supprimer les expertise de dangerosité?', RSC 21 (2011); J.-L. Senon and C. Manzanera, 'Psychiatrie et justice: de nécessaires clarifications à l'occasion de la loi relative à la rétention de sûreté', AJ Pénal 176 (2008); C. Protais and D. Moreau, 'L'expertise psychiatrique entre l'évaluation de la responsabilité et de la dangerosité, entre le médical et le judiciaire. Commentaire du texte de Samuel Léé', Séminaire GERN 'Longues peines et peines indéfinies. Punir la dangerosité', Paris, 21 March (2008); M. Benezec, T.H. Pham \& P. Le Bihan, 'Les nouvelles dispositions concernant les criminels malades mentaux dans la loi du 25 février 2008 relative à la rétention de sûreté et à la déclaration d'irresponsabilité pénale pour cause de trouble mental: Une nécessaire évaluation du risque criminel', 167 Annales Médico-Psychologiques 39 (2009).

22. P. Conte, S. Tzitzis \& G. Bernard, Peine, dangerosité. Quelles certitudes? (2010).

23. P. Mbanzoulou, 'La dangerosité', in M. Herzog-Evans (ed.), Transnational Criminology Manual, Volume I (2010) at 109.

24. A. Baratta, A. Morali \& O. Halleguen, 'La dangerosité des malades mentaux bénéficiant de L'article 122-1. A propos d'une étude rétrospective portant sur 58 cas', 88 L'information psychiatrique 559 (2012).

25. In this vein: F. Fiechter-Boulvard, 'La dangerosité: encore et toujours...', AJ Pénal 67 (2012).

26. Ibid

27. Herzog-Evans (2015), above n. 18

28. O. Halleguen, 'Prise en charge des patients psychiatriques dangereux', presentation at the conference of the Institut pour la Justice, December 14 - PDF of the presentation available at: $<w w w$.institutpourlajustice. org/wp-content/uploads/2012/10/EA-N\%C2\%B014_mail1.pdf> (last visited 7 November 2015) (2013).

29. M. Borch-Jacobsen, J. Cottraux, D. Pleux, J. Van Rillaert \& C. Meyer, Le livre noir de la psychanalyse. Vivre, penser et aller mieux sans Freud (2005). particularly those operating in Centres Nationaux d'Evaluation (CNE - National Assessment Centres), which are in charge of an additional level of assessment required by some safety measures.

The recent safety measure created by Ms Taubira relies on a more reliable criterion: it applies to offenders who have been declared partially irresponsible by reason of insanity, according to Article $122-1$ of the PC (Art. 706-136-1 of the PPC).

\subsubsection{General Presentation of the Legal Framemork}

The rules governing SSJ and safety measures are so complex that this article will present a table rather than engaging in endless descriptions (see next page).

Under the current French Constitution (1958), it is the executive power, i.e. the government, who submits laws to the legislature, which has little room to manoeuvre when it comes to discussing Bills. Moreover, only Bills submitted by the executive have a chance to be registered in the Parliament's diary. The 1958 Constitution also allows the executive to benefit from its own very large legislative domains. ${ }^{30}$ Lastly, administrations, and particularly the prison services, regularly issue internal circulars that infringe on the domains of both decrees and laws, and this is alas particularly true in the case of criminal law. ${ }^{31}$ In view of these Constitutional principles, SSJ and safety measures were created by laws, but the details of their regime have been subjected to several decrees. ${ }^{32}$ To summarise, the executive enjoys considerable legislative powers.

\subsection{Procedural Provisions}

SJJ abides by ordinary criminal procedure regulations pertaining to sentencing, which comprise public hearings, the rights to counsel and to appear in court for an adversarial hearing, and access to the file and other due process principles. ${ }^{33}$ For safety measures, a host of procedural safeguards have been put in place, which has contributed to their limited use. However, from a human rights viewpoint, they do not sufficiently compensate for the aforementioned loose criteria. As shown in Table 2 on page 75, except for the right to appear in court, to have access to the file, and to counsel and appeal, most of the rules vary from one measure to another. Reformers have considered that the higher the court making the decision, the more protected offenders would be. A more stringent condition appears to be the three layers of risk assessment imposed by most safety measures: a) by an expert; b) after a placement of up to six weeks in the aforementioned CNE, by these centres' multidisciplinary teams of practitioners; and c) by a socalled multidisciplinary commission for safety measures (Commission multidisciplinaire des mesures de sûreté -

30. F. Mitterrand, Le coup d'état permanent (1964); D. Rousseau, 'L'objet de la Constitution ce n'est pas l'Etat mais la société', Critique 428 (2012).

31. For illustrations, see Herzog-Evans (2016), above n. 14, spe. chap. 01, and in the case of safety detention, see M. Herzog-Evans, 'Les textes d'application de la loi Rétention de sûreté, Recueil Dalloz 3098 (2008).

32. Ibid.

33. S. Guinchard and B. Buisson, Procédure pénale, 10th edn (2014). 

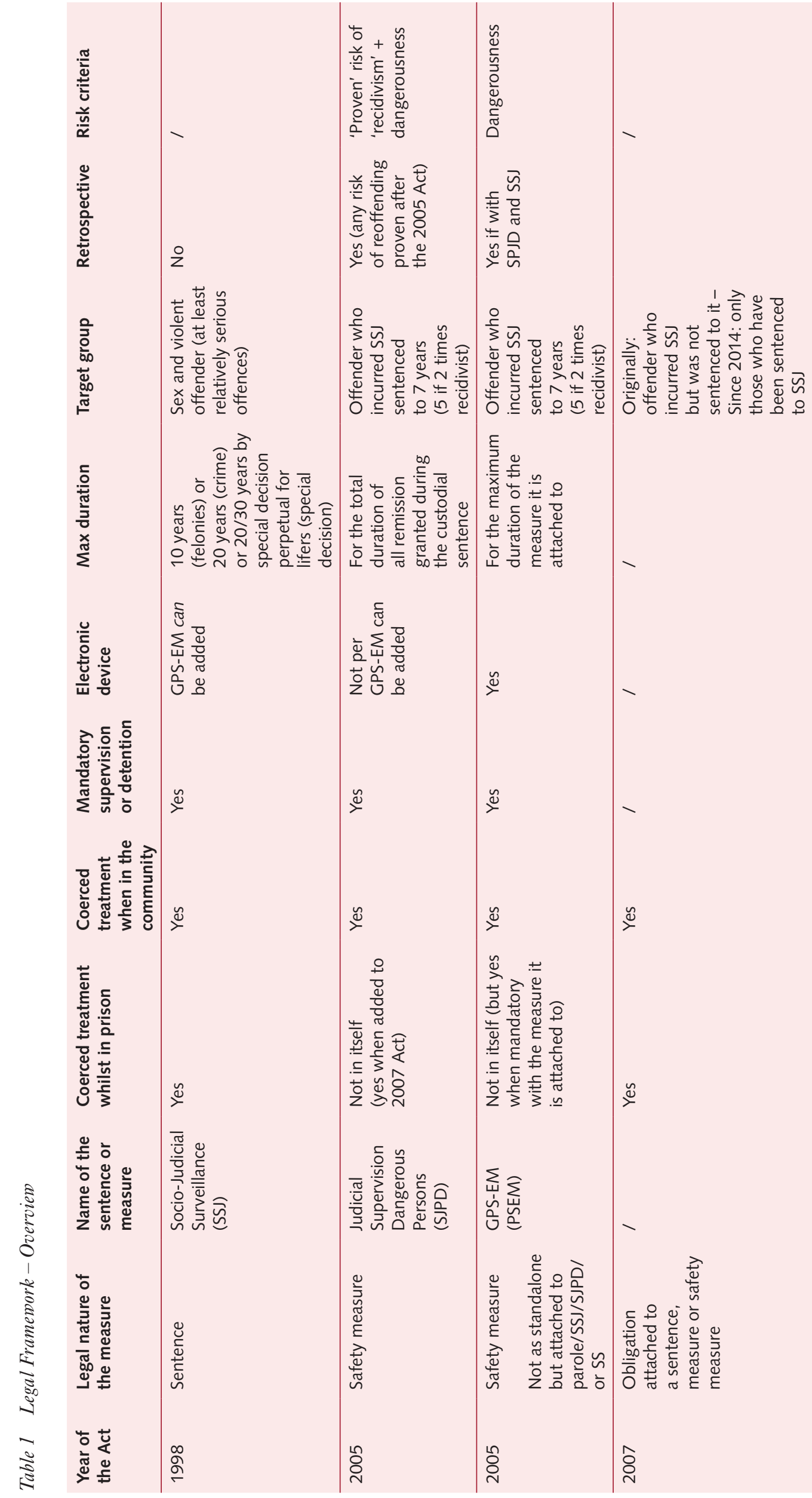


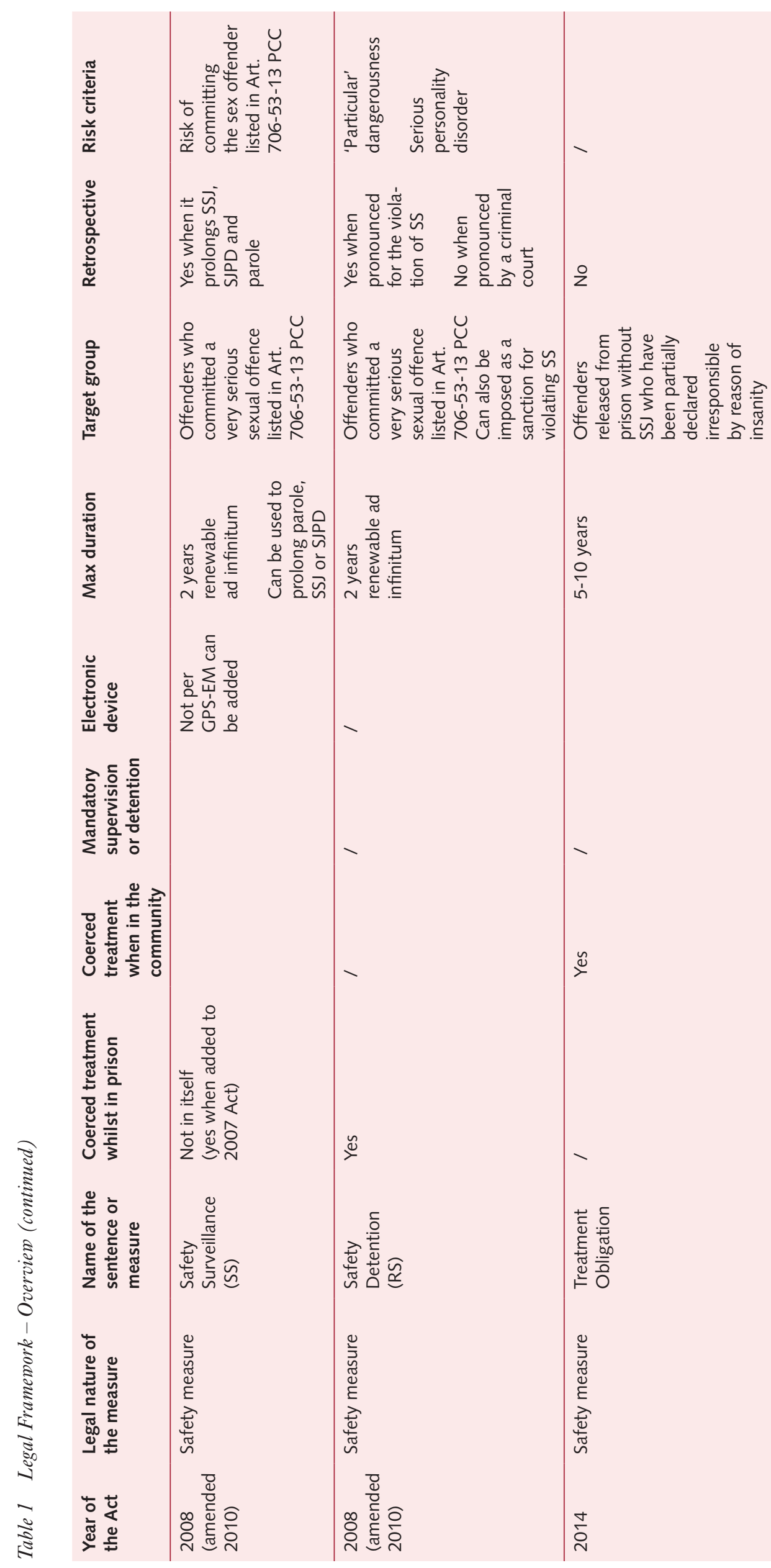


CPMS). The reason why these layers limit the number of safety measures that are being imposed is that they take a minimum of six to twelve months to complete, which is a precious time that many courts do not have and a very costly and demanding system in terms of material and human resources. Moreover, judges are not impervious to the fact that CPMS is not composed of risk assessment experts, but of lawyers, gendarmes and laypersons, along with one psychologist or psychiatrist. In practice, they simply follow the conclusions contained in the expert testimony or in the CNE reports. ${ }^{34}$ However, because, in most cases, none of the aforementioned will have used evidence-based tools, an exceptionally high level of false negatives or false positives is to be expected, ${ }^{35}$ which is not compensated by a right to a counter-assessment. Indeed, if the offender asks for a counter-assessment, he depends on the good will of the judge, who has the discretion to determine whether to appoint another state-funded expert or whether the offender must pay privately for an independent expert, which would not be covered by legal aid. ${ }^{36}$

Public hearings are not the rule in the implementation of French sentences, as legislators have always considered that people's privacy was more important at this stage of the criminal process. ${ }^{37}$ However, with the more stringent safety measures (SS and RS), the offender who requires a public hearing is obligatorily granted one. In practice, very few offenders actually request a public hearing, many preferring it to be held in camera. ${ }^{38}$ More debatably, with $\mathrm{RS}$, most hearings are held via videoconferencing, ${ }^{39}$ which creates difficulties for the defence. ${ }^{40}$

Astonishingly, the Taubira Act (2014) has not implemented a single procedural safeguard beyond the basic due process rules, and even those due process rules are the result of doctrinal interpretation, as the law is completely silent on this point. ${ }^{41}$ The competence lies with a single judge court, the sentence implementing judge (juge de l'application des peines - JAP), that is a judge in charge of release, sanctions and supervising offenders serving a community sentence or measure. Moreover, rather than requiring expert testimony, the law originally only requested a 'medical opinion'. Fortunately, a decree has 'corrected' the law - a classic violation of a superior norm, but in this case a welcomed one - and stipulated that it should, in fact, be an independent expert.

Importantly, none of the procedures - with the exception of SSJ and RS, when they are pronounced ab initio

34. A. Morice and N. D'Hervé, Justice de sûreté et gestion des risques. Approche pratique et réflexive (2010).

35. And found: A. Baratta, A. Morali \& O. Halleguen, 'La vérité sur l'expertise post-sentencielle: évaluation clinique contre échelle actuarielle', 170 Annales Médico-Psychologiques 96 (2012).

36. Herzog-Evans (2016), above n. 14, spe. chap. 811

37. Ibid., chap. 01.

38. G. Lorho, 'L'audience devant la JRRS', AJ Pénal 109 (2014).

39. Ibid.

40. V. Bianchi, 'Quels droits de la défense pour la personne placée sous surveillance de sûreté ou en rétention de sûreté?' , AJ Pénal 106 (2014)

41. Herzog-Evans (2016), above n. 14, spe. chap. 537 by a criminal sentencing court - allow the victim to be present in court or to be represented.

2.5 Maximum Length of Mandatory Supervision As seen in Table 1, SSJ can be perpetual when it follows the release of a lifer, and is otherwise potentially very lengthy, although, as we shall see later, courts have been quite reasonable in that respect. SJPD typically lasts for two to three years, depending on the extent to which offenders have benefited from remission for good conduct (Art. 721 PPC) or for re-socialisation efforts (Art. 721-1 PPC). Before the 2014 Act, remission granted to recidivists was half of the length, which was granted to first-time offenders, with the paradoxical consequence that they could be supervised under SJPD for shorter durations. The 2014 Act has abrogated this discrimination. It is precisely because the length of SJPD could not exceed that remission, thereby ensuring that the total length of social control exercised upon the offender would not exceed the total length of the pronounced custodial sentence, that the Constitutional Council (CC) had initially declared SJPD compatible with the constitution. However, legislators wanted to control sex offenders for extended periods of time and to allow for the prolongation of shorter measures. This is why the 2008 Act allowed SS to be used in order to prolong SSJ and SJPD (and incidentally, parole). The first decision was to be made for one year (two as of the 2010 Act) and could be renewable ad infinitum. In other words, via $\mathrm{SS}$, legislators have allowed the courts to perpetually prolong a sentence (SSJ), a release measure (parole) and a temporary safety measure (SJPD), in direct violation of the principle of legality.

\subsection{Conditions Attached to Safety Measures} In spite of such shocking violations of the general principles of criminal law, what can actually be imposed in most cases is an ordinary form of probation, which means the offender is placed under the supervision of a JAP and a probation service. This ordinary probation is thus usually regulated by exactly the same rules as those governing community sentences and measures (i.e. Arts. 132-44 and 132-45 PC), with most judges choosing just a few amongst the twenty-two possible obligations listed in Article 132-45. These generally are paying damages, fixing one's abode at a particular address, getting treatment and seeking employment. The main difference in cases involving sex offenders is that the courts tend to add contact-restraining obligations. ${ }^{42}$ When a specific treatment 'injunction' (as opposed to a regular treatment 'obligation') is imposed, as provided for in the rules governing SSJ (which can be imposed for SJPD, with or without PSEM, and for SS), two medical practitioners are in charge of supervision instead of one: a coordinating doctor and a treatment doctor. Rather than adding to the pressure on the offender, one of them, the 'coordinating doctor' acts as a shield between the JAP and

42. For the Courts' typical practices, see M. Herzog-Evans, French Reentry Courts: Mister Jourdain of Desistance (2014). 


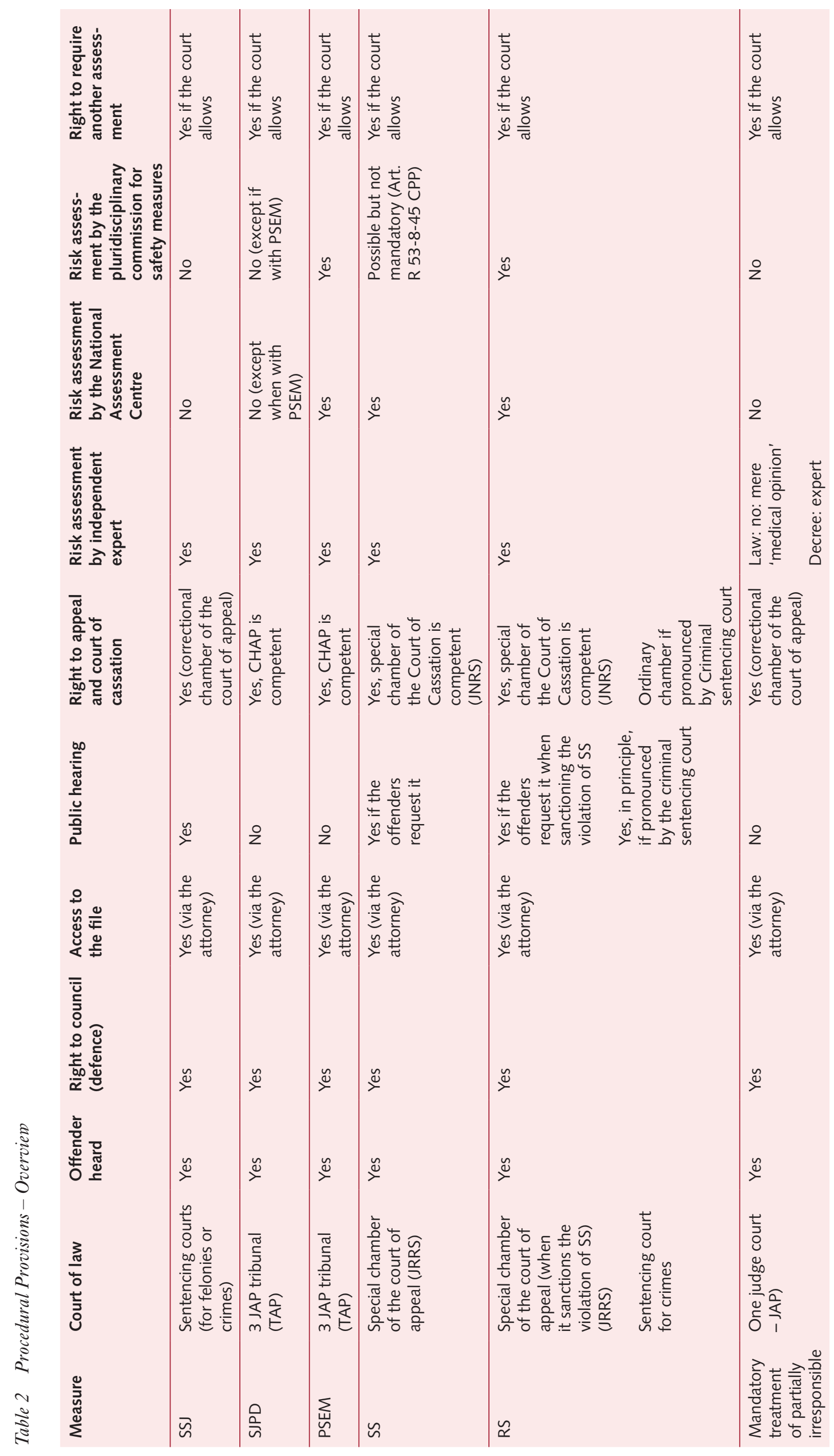


the offender, in order to better protect his privacy against potential violations of the principle of professional secrecy. Offenders are thus better protected than they would be with regular probation with an ordinary treatment obligation. Recently, however, violations of the secrecy principle were imposed in the latest Sarkozy reforms (2010-2012), which, in particular, allow a health practitioner to bypass the coordinating doctor and to communicate to the JAP that some changes are occurring that are increasing the level of risk.

Other than that, offenders' liberties are not impacted much more than those of regular probationers. Notably, bans or even controls on their use of computers or the Internet cannot be imposed. ${ }^{43}$ It is only when it is established that they have committed a non-contact sex offence (such as downloading paedo-pornographic images or videos) that they can be sentenced. Without adequate control, this is bound to be rare. In the same vein, under the current legislation, there is simply no way to regularly control their alcohol or drug intake, and no alcohol consumption ban can be imposed; offenders can only be banned from going to bars which leaves them free to buy as much alcohol as they want from supermarkets. ${ }^{44}$

It is only when PSEM is added to a sentence or measure that it becomes very stringent because PSEM technology is not discreet and is extremely dysfunctional, as we shall see next. Safety detention is perhaps the most shocking of all of the measures because it deprives exoffenders of their liberty when they have not committed a new offence. It is therefore reassuring that this measure has hardly ever been used.

\subsection{Practical Use of Safety Measures}

The overall use of SSJ increased during the first year, but has stabilised since 2010. However, SSJ is still far from being systematically imposed on sex offenders. For instance, in 2010 , only $39.1 \%$ of the total sentences for rape comprised SSJ, whilst the use of SSJ with other sex offences ranged from $4.4 \%$ to $9.4 \%$. Judges tend to impose SSJ much more frequently when there are several sex offences. They pronounce it in $87.5 \%$ of multiple rape cases; likewise, when the person is a reoffender, he has 4.7 times more chance of being thus sentenced. Conversely, a minor incurs 4.2 times less risk of being sentenced to SSJ. ${ }^{45}$ Overall, the length of SSJ has been quite reasonable, and far from the legal maximum, even from the very beginning of its implementation. ${ }^{46}$ Official statistics published in $2013^{47}$ reveal that the average

43. A recent case examined by the Civil Tribunal of Reims (Reims, TGI, Ord Référé, 28 September 2011, No. 11/00180) thus had to reject the victim's application for the offender to be banned from using Facebook, available at: <www.numerama.com/magazine/19996-un-ex-delinquant -sexuel-echappe-a-l-exclusion-des-reseaux-sociaux.html> (last visited 8 November 2015).

44. Herzog-Evans, (2016), above n. 14, spe. chap. 613.

45. R. Josnin, 'Le recours au suivi socio-judiciaire', 121 Infostat Justice February (2013).

46. V. Carrasco, 'Le suivi socio-judiciaire: bilan de l'application de la loi du 17 juin 1998', 94 Infostat Justice May (2007).

47. R. Josnin, 'Le recours au suivi socio-judiciaire', 121 Infostat Justice February (2013). length is six years for crimes and five years for felonies, and paedophiles tend to be sentenced to longer SSJ than other sex offenders. Recidivists also serve longer SSJ sentences: eight years on average, as opposed to six for a criminal.

It is very difficult to obtain data pertaining to the use of safety measures. There simply are no regular public statistics published on this subject. Most of what we know was published in a Parliamentary report, 'the Blanc Report', ${ }^{48}$ in 2012. We thus learn that $80 \%$ of PSEM are pronounced in sex offence cases and that, in most of these cases, the measure is pronounced alongside a SJPD safety measure. The figures are rather low: in 2011, only 53 people were subjected to PSEM, and a total of 132 people were subjected to PSEM from 2007 to 2011. The percentage of recall over this period was $25 \%$. If this measure has not been used frequently, it is because of the judiciary's mistrust in safety measures in general. In the case of PSEM, it is also because the technology is far from being operational. Many cases of alarms ringing whilst the person was in court or at the probation service for a regular meeting have been reported, ${ }^{49}$ along with multiple occurrences where the person was awakened several times during the night by a dysfunctional alarm or perhaps by deliberately malicious behaviour on the part of the monitoring team.

There are unfortunately no official data on SJPD, with the result that, incredibly, there is no way of knowing how frequently it is being used. ${ }^{50}$ The same is astonishingly true with SS. However, in this case, in 2012, a Parliamentary question was put to the Ministry of Justice, ${ }^{51}$ which answered that, by 20 December 2012, twenty-two people had been submitted to SS since the enactment of the 2008 Act. The Ministry of Justice also revealed that nineteen were still under supervision. The Ministry added that, in most cases, SS had been pronounced in order to prolong SJPD and that most of them pertained to sex offences. ${ }^{52}$

We know of the imposition of RS via the media, which tells us just how rarely it happens. In practice, five people have so far been placed under safety detention for very short periods of time, as revealed by the Deprivation of Liberty General Controller (Contrôleur général des lieux de privation de liberté - hereafter the Controller) in $2015 .^{53}$

None of the practices described here have been evaluated academically. However, some reports have

48. E. Blanc, Rapport d'information sur le suivi des auteurs d'infractions à caractère sexuel, en conclusion des travaux d'une mission d'information relative à l'exécution des décisions de justice, Commission presided over by M. J.-L. Warsmann, 29 February, National Assembly, No. 4421 (2012).

49. Ibid

50. We also asked the people in charge of the intranet data available to judges, which are not communicated to the public, whether data existed, but were not published. We were told that no such data were collected at all.

51. Written Question No. 00845 by M. Jacques Mézard, Senator, JO Sénat 19 July (2012)

52. Ministry of Justice Answer, JO Sénat 20 December, 3007 (2012).

53. CGLPL, Avis du 5 octobre 2015 relatif à la rétention de sûreté, JO 5 November, 59 (2015) 
addressed their implementation. The aforementioned Blanc report (2012) recommended that more evidencebased assessment and treatment should be delivered in the case of safety measures and SSJ.

\subsection{Jurisprudence's Control over Safety Measures}

Immediately after a law is passed, and before it is promulgated by the president of the Republic, members of both chambers of the Parliament (National Assembly and Senate) can refer it to the CC for an appraisal of its constitutionality. This first-line control of the legislation presented in this article was seized by the MPs in $2005,{ }^{54} 2008^{55}$ and $2014 .{ }^{56}$ In each case, the CC considered that the new measures were compatible with the Constitution, and particularly, with the constitutional principles of necessity, in spite of the perpetual nature of several of them. However, in the case of RS, the CC attempted to limit its retrospective nature, whilst turning a blind eye to this very retrospective nature in the case of SS. The CC stated that it could not be retrospective when RS is pronounced by a criminal court. This led to a special commission ${ }^{57}$ consulted by the then Minister of Justice Ms Dati, which stated that when RS was pronounced as a sanction for the violation of SS, it could conversely be retrospective. To ensure this would be the case, Nicolas Sarkozy had it set in legislative stone with a new 2010 Act without, it must be noted, meeting any significant opposition.

Overall, first (sentencing courts, JAP, TAP, JRRS) and second (courts of appeal) level courts have been extremely cautious in the use of SSJ and safety measures. Most courts have preferred to opt for regular forms of supervision, first because it ensures that legal principles are not violated. Indeed, French courts are very attached to the principles that regulate criminal law and in particular the principle of legality, the consequence being that any piece of legislation that infringes this principle is typically ignored or marginalised. A second reason why courts have preferred regular forms of supervision can be found in JAP and TAP's professional culture: their main guideline is rehabilitation and desistance. A third obstacle to the wide implementation of safety measures has been practical in nature: courts are well aware that there simply are not enough psychiatrists (particularly in the case of a treatment injunction, where two psychiatrists are required) and probation officers to adequately supervise offenders, even those who have committed serious crimes.

Most courts have fourthly been very constrained by the dangerousness or reoffending risk criteria, particularly in the case of SJPD, for which they have to be 'proven'. Thus, one court, for instance, rejected the prosecutor's requisitions for SJPD pertaining to an offender who had

55. CC, 21 février 2008, no. 2008-562 DC.

56. CC, 7 août 2014, no. 2014-696 DC.

57. V. Lamanda, Amoindrir les risques de récidive criminelle des condamnés dangereux, Rapport au président de la République, 30 May (2008). committed a sex offence against a minor under the age of 15 , because, in his case, experts had indicated that 'he may benefit from treatment', which meant that his risk of reoffending had not been 'proven'. ${ }^{58}$ In the same case, though, the court of appeal then pronounced SJPD - retrospectively, with regard to the date of the offence - which was confirmed by the Court of Cassation. ${ }^{59}$

Courts have also exercised control over the execution of the two most stringent safety measures. In the case of PSEM, administrative courts have considered that the prison services should do a better job of protecting offenders from 'serious infringements on their private lives' (notably being awakened several times during the night) as a direct result of the poor technology used in the case of PSEM, although, in one particular instance, the offender's application failed, as he had not used an adequate procedure. ${ }^{60}$ In the case of RS, the Court of Cassation (JNRS chamber) overturned a placement in RS where the court and experts had assessed the person as being dangerous solely based on the fact that he refused to submit to treatment. ${ }^{61}$ For its part, the Controller recently criticised this measure's regime in no uncertain terms, stating in particular that it violated all of the general principles of criminal law and procedure (specifically, the principles of legality and the prohibition of retrospective criminal laws that are harsher), that detention was too similar to regular prison detention, and therefore violated the principle of proportionality, and that the treatment offered was of insufficient quality. However, she complimented the prison services for the good conditions of detainees' quarters and cells. She nonetheless called for the outright abolition of safety detention. $^{62}$ The highest administrative Court, the Council of State, has abrogated the Fresnes RS centre's internal regulations pertaining to visitations and correspondence, precisely because they were too similar to prison regulations and were therefore too restrictive. ${ }^{63}$ Conversely, and quite contradictorily, the Council of State refused to abrogate another decree that had initially allowed the institution of such restrictions. ${ }^{64}$

Moreover, most jurisdictions have had no trouble in implementing SJPD, PSEM and SS retrospectively, with only a few exceptions. ${ }^{65}$ With PSEM, in big cities, where schools, kindergartens and sports settings for children abound, some offenders must be limited to a very strict perimeter, which, contrary to the general legal principle governing criminal law, has not led to

58. TAP Agen, 8 June 2009, no. 200700102931, AJ Pénal 421, obs. M. Herzog-Evans (2009).

59. Court of Cassation, Criminal Chamber, 1 April 2009, AJ Pénal 321, obs. M. Herzog-Evans (2009).

60. CE 26 October 2011, Beaumont, Applic. No. 350081, AJDA. 434, note G. Eveillard (2012)

61. JRRS, 17 December 2014

62. CGLPL, Avis du 5 octobre 2015 relatif à la rétention de sûreté, JO 5 November 59 (2015)

63. CE 31 October 2011, Applic. No. 332707

64. CE 26 November 2010, Applic. No. 323694

65. Court of Appeal, CHAP, Versailles, 1 April 2008, AJ Pénal 323, obs. M. Herzog-Evans (2008). 
significant judicial control. ${ }^{66}$ This is in direct violation of Article IV-19 of the Recommendation CMRec(2014)4 on electronic monitoring, which states: 'In cases where electronic monitoring relates to exclusion from, or limitation to, specific zones, efforts shall be made to ensure that such conditions of execution are not so restrictive as to prevent a reasonable quality of everyday life in the community'.

\subsection{Authorities in Charge of Supervision and Breach}

It is the JAP, a general release and re-entry court, assisted by state probation officers - and in many cases, with the added support of the third sector - which are in charge of supervising offenders serving a SSJ or a safety measure. Again, in this respect, there is no difference from a regular form of probation. In some cases, the JAP may ask the police to conduct an investigation, but in practice the police do not like being associated with the supervision of people serving community measures, preferring to focus on those who have not yet been sentenced.

Importantly, these practitioners and agencies work separately, and sequentially, rather than in an integrated way. There is no French equivalent to England and Wales' MAPPA, ${ }^{67}$ and quite conversely, the overall attitude and culture are rather territorial and corporatist, ${ }^{68}$ with the consequence that collaboration is rather rare. ${ }^{69}$ As a result, the flow of information between practitioners is not sufficient, which sometimes contributes to crimes being committed. ${ }^{70}$

The rules governing sanctions for the violation of SSJ and safety measures are complex and intricate, and Table 3 attempts to clarify these rules (see next page). Sanctions can also apply when the person refuses SJPD, PSEM or treatment. In most of these cases, the rules are laid down either in the PC or the PPC, and fair trial and procedural principles apply. However, with the exception of SS and RS, for which the JRRS is still competent, when the sanction is custodial, it is systematically imposed by the JAP, not a collegial court. It is also note-

66. Such as in this case, where the court de facto limited the offender to one street block: Court of Appeal (CHAP) Bordeaux, 29 Mai 2009, AJ Pénal 509, obs. M. Herzog-Evans (2009).

67. J. Wood and H. Kemshall, The Operation and Experience of MultiAgency Public Protection Arrangements (MAPPA), Home Office Online Report 12/07 (2007).

68. M. Herzog-Evans, 'Explaining French Probation: Social Work in a prison Administration', in I. Durnescu and F. McNeill (eds.), Understanding Penal Practice (2013) 63; and 'France: Legal Architecture, Political Posturing, 'Prisonbation' and Adieu Social Work', in G. Robinson and F. McNeill (eds.), Community Punishment. European Perspective (2015) 51.

69. M. Herzog-Evans, "“All Hands on Deck": (re)mettre le travail en partenariat au centre de la probation', AJ Pénal March: 139 (2013).

70. As in the Chloé case (2013), where a probation officer simply sent a fax to the JAP informing him/her that a sex offender had disappeared, rather than contacting him/her in person (the fax machine happened to be out of order), allowing the offender to abduct and rape a young girl for an entire week, before they were miraculously found by the police in Germany thanks to a road accident. See Television Network France Info, available at: <www.francetvinfo.fr/faits-divers/enlevements/lesrates-de-la-justice-dans-l-affaire-chloe_173177.html> (last visited 7 November 2015). worthy that, for the recently added safety measure, the 2014 Act has again opted for the application of ordinary sentencing rules, rather than granting competence to the JAP. This is a sign of defiance towards the JAP, which has been perceptible in recent years, ${ }^{71}$ notably because the prison services have become extremely powerful and have been put in charge of drafting sentence implementation Bills. The JAP's role - or the prosecutor's - is to refer a violation of a treatment order to a felony court, which can impose a sentence for two years' imprisonment, along with a fine of 30,000 euros.

\subsection{Evidence-Based Practices}

When most of the reforms presented in this article were enacted, there was no debate pertaining to their compatibility with the current state of scientific knowledge. France continues to lag behind in evidence-based practices (EBP), and it was only recently made aware of EBP during a 'Consensus Conference' held in February $2013 .^{72}$ For the most part, the treatment of sex offenders comprises anti-androgens (when the person is cared for by a psychiatrist, which is not always the case) and/or psychoanalysis or psychodynamics therapy, although the latter is of little use, ${ }^{73}$ and the former must be complemented by cognitive-behavioural treatment (CBT), as the Medical Academy has recently acknowledged. ${ }^{74}$

Since 2008, French prison and probation services have tried to put in place spurious Risk-Needs-Responsivity programmes called PPR (programmes de prevention de la récidive: reoffending prevention programmes) - the acronym subliminally evoking RNR. Such programmes, however, have little to do with EBP, and an implementation study $^{75}$ revealed that they actually comprise 'loose' psychodynamic-like group work, and has little to do with $\mathrm{CBT}^{76}$ The programmes have been extended nationwide in spite of the lack of outcome evaluations and serious concerns over their potential negative

71. A. Gentilini, 'Le juge de l'application des peines: vers une disparition?', in F. Ghelfi (ed.), Le droit de l'exécution des peines. Espoirs ou désillusion (2014) 107; M. Herzog-Evans, 'La déjuridictionnalisation de l'application des peines', in S. Boussard (ed.), Les droits de la personne détenue (2013) 259.

72. See the conference website, available at: <http://conference-consensus. justice.gouv.fr/> (last visited 8 November 2015). Also see pertaining to France's backwardness in terms of risk assessment: M. Herzog-Evans, 'Outils d'évaluation: sortir des fantasmes et de l'aveuglément idéologique', AJ Pénal 75 (2012); and in terms of treatment: M. Herzog-Evans, Moderniser la probation française. Un défi à relever (2013).

73. See inter alia W.L. Marshall, Y.M. Fernandez, L.E. Marchall \& G. A. Serran (eds.), Sexual Offender Treatment. Controversial Issues (2006); D.R. Laws and W.T. O'Donohue (eds.), Sexual Deviance. Theory, Assessment, and Treatment (2008)

74. Académie de Médecine, 'La prévention médicale de la récidive chez les délinquants sexuels', 194 Bulletin de l'Académie nationale de médecine 1033 (2010)

75. V. Moulin, Les groupes de parole de prévention de la récidive des personnes placées sous main de justice, Mission Droit et Justice, April (2012)

76. O. Vanderstukken and M. Benbouriche, 'Interventions cognitivo-comportementales et prise en charge des auteurs d'agression sexuelle en France: entre Santé et Justice', in J.-L. Senon, G. Lopez \& R. Cario (eds.), Psycho-criminologie: clinique, prise en charge, expertise (2012) 123. 


\begin{tabular}{|c|c|c|c|c|}
\hline Measure & Custodial & Non-custodial & Fair trial and appeal & Competent court \\
\hline SSJ & $\begin{array}{l}\text { - Execution of the cus- } \\
\text { todial sentence deter- } \\
\text { mined in advance by } \\
\text { the sentencing court } \\
\text { in case of a future } \\
\text { violation ( } 3 \text { years for } \\
\text { felonies and } 7 \text { years } \\
\text { for crimes) }\end{array}$ & $\begin{array}{l}\text { - Adding PSEM } \\
\text { - Adding more obliga- } \\
\text { tions or increasing the } \\
\text { number of appoint- } \\
\text { ments with the pro- } \\
\text { bation officer or JAP }\end{array}$ & Yes & JAP \\
\hline SJPD & $\begin{array}{l}\text { - Remission withdraw- } \\
\text { al, partial or total } \\
\text { (return to prison to } \\
\text { serve the sentence) }\end{array}$ & - Adding PSEM & Yes & JAP \\
\hline PSEM & $\begin{array}{l}\text { Depends on the measure } \\
\text { to which it is attached: } \\
\text { - Revocation of parole } \\
\text { - Remission withdrawal } \\
\text { (SJPD) } \\
\text { - RS (if with SS) }\end{array}$ & $\begin{array}{l}\text { - Adding more obliga- } \\
\text { tions or increasing the } \\
\text { number of appoint- } \\
\text { ments with the pro- } \\
\text { bation officer or JAP }\end{array}$ & Yes & JAP \\
\hline SS & $\begin{array}{l}\text { - Placement in } \mathrm{RS} \text { for a } \\
\text { maximum of } 2 \text { years, } \\
\text { renewable ad infini- } \\
\text { tum }\end{array}$ & $\begin{array}{l}\text { - Adding PSEM } \\
\text { - Adding more obliga- } \\
\text { tions or increasing the } \\
\text { number of appoint- } \\
\text { ments with the pro- } \\
\text { bation officer or JAP }\end{array}$ & Yes & $\begin{array}{l}- \text { JRRS if custodial } \\
\text { - JAP if non-custodial }\end{array}$ \\
\hline RS & $\begin{array}{l}\text { None, other than its } \\
\text { probable prolongation }\end{array}$ & / & Yes & JRRS \\
\hline $\begin{array}{l}\text { Mandatory treatment if } \\
\text { partially irresponsible } \\
\text { offender }\end{array}$ & $\begin{array}{l}\text { Two-year custodial sen- } \\
\text { tence }\end{array}$ & Fine of 30,000 euros & Yes & Sentencing court \\
\hline
\end{tabular}

impact. ${ }^{77}$ In most cases, however, community treatment of sex offenders is implemented by local and unspecialised psychiatrists or psychologists, although in recent years specialised centres called CRIAV (Centres de Ressources pour les Intervenants auprès des Auteurs de Violences Sexuelles - Resources Centres for Practitioners in charge of Sex Offenders) have been created, some of which are currently trying to become informed about EBP. It is noteworthy, however, that France has yet to create an accreditation panel comprising internationally renowned specialists who are able to discriminate between EBP and non-EBP programmes. As we have seen, risk assessment is, so far, largely based on non$\mathrm{EBP}$, whether it is conducted by 'experts' or by proba- tion officers, although there are now modest signs of change. $^{78}$

EBP are contentious for a number of reasons. First, they are wrongly assimilated to punitive policies, and as was mentioned previously, most issues pertaining to crime are highly politicised in France. Secondly, they go against the deeply ingrained psychoanalysis background of most health practitioners, who tend to be hostile to CBT. A third reason is that they require structure and protocols, which breaks with discretionary traditions.
77. O. Vanderstukken and $M$. Benbouriche, 'Principes de prévention de la récidive et principe de réalité en France: les programmes de prevention de la récidive à la lumière du modèle "Risque-Besoins-Réceptivité "', AJ Pénal November 522 (2014). For a more optimistic view, see R. Palaric, 'Les groupes de parole de prévention de la récidive en France: observation des effets produits', 21 Pratiques Psychologiques 259 (2015).
78. See, for instance, J.-P. Guay and D. Lafortune, 'L'évaluation du risque de récidive et l'intervention basée sur les données probantes: les conditions nécessaires à l'implantation de méthodes structurées d'évaluation et d'intervention efficace', 21 Pratiques Psychologiques 293 (2015). 


\section{The Place of Safety Measures within the Legal System}

\subsection{Character of the Framework}

'Safety measures' by definition correspond to a legal label that attempts to justify that such measures do not have to abide by general criminal law rules. There is therefore no doubt that SJPD, PSEM, SS and RS are indeed 'safety measures'. Conversely, if SSJ appears at first glance as being a 'sentence', thereby abiding by general criminal law principles, in reality its regime is mixed. It is a sentence in the sense that it is indeed used to punish a person who has committed an offence and is pronounced by sentencing courts. However, it leads to a (post release) mandatory supervision and treatment regime that is similar to that of safety measures, and can be prolonged via $S S$, a safety measure.

The concept of safety measure is indeed rather blurry. It is originally derived from the School of Social Defence as modernised by Marc Ancel, ${ }^{79}$ and had all but disappeared by the time the New Penal Code of 1994 was enacted. At that time, it was all but forgotten in the renewed legal framework. However, safety measures were resuscitated during Nicolas Sarkozy's era and are now firmly part of the criminal law landscape, notably via the dangerousness criterion. ${ }^{80}$ Previously, the concept of a safety measure appeared to be outdated, because it did not fit within a society that, at the time, did not yet use crime as a political tool, and because the legal doctrine had struggled to distinguish between sentences and 'safety measures', regardless of how hard it had tried to do so. ${ }^{81}$ Indeed, a safety measure is supposedly not a sentence, but does apply exclusively to offenders, with this minimal difference: rather than aiming at punishment or rehabilitation, it aims at protecting public safety. However, in most cases, it is certainly perceived by the offender as being punitive because of its controlling and constraining nature, and in their current state and focus on treatment, most safety measures also endeavour to rehabilitate. Moreover, most sentences likewise aim at protecting the community. In other words, the distinction between safety measures and sentences is so blurry that it cannot predictably be used in a democratic society governed by the principle of legality.

Nonetheless, French Courts have used the distinction to justify violations of general criminal law principles, in particular, Article 7 of the European Human Rights Convention and its nearly identical formulation in Article 8 of the French Declaration of Human Rights

79. M. Ancel, La défense sociale nouvelle (1966).

80. J. Danet, 'La dangerosité, une notion criminologique séculaire et mutante', Champ Pénal (2008), available at: <http://champpenal.revues.org/ 6013> (last visited 8 November 2015).

81. M. Patin 'La place des mesures de sûreté dans le droit positif moderne', RSC 415 (1948); V.R. Schmelck, 'La distinction entre la peine et la mesure de sûreté', in Collective, Mélanges Patin (1965) 181.
(Déclaration des Droits de l'Homme et du Citoyen - DDH - 1789). For instance, such has been the case for France's mandatory commitment of mentally ill offenders, a measure that is regulated by Article 706-136 of the PPC, an article situated right before the newly created mandatory treatment established by the 2014 Act (Art. 706-136-1 PPC). ${ }^{82}$ It does not help because the European Human Rights Court has recently ruled similarly that the mandatory commitment of mentally ill persons was not a sentence and, therefore, that Article 7 did not apply. ${ }^{83}$ The reasoning behind this ruling is that this measure applies to former offenders who have been deemed partially irresponsible by reason of insanity, in the same vein as the newly created 2014 Act. For the ECHR, what counts is that the decisions pronouncing such safety measures are not in themselves 'sentencing' decisions, but are merely stating that the person has a condition that is disposed to lead to legal consequences. In its aforementioned 2008 decision, the CC ruled that Article 8 of the DDH was not violated because safety measures are 'not pronounced because of the person's guilt' but because of 'his particular dangerousness' ${ }^{84}$

In essence, however, safety measures are also put in place because French sentences for sex offenders are quite lenient, with an average of eight years for rapists, ${ }^{85}$ and therefore, correspond to a deinstitutionalisation movement. As Razac aptly puts it, they may be perceived as being 'the ambulatory treatment of a behavioural anomaly, which is a source of danger for the community'. ${ }^{86}$

\subsection{Alternatives for Prevention}

In France, sex offenders can only be the target of criminal or health law measures. Civil law does not deal with legal issues other than contract, family or torts. With regard to criminal law, in most cases, sex offenders are sentenced to regular custodial or community sentences. They are thus submitted to regular probation and treatment obligations. They can benefit from early release measures such as parole and many others, ${ }^{87}$ and mandatory treatment is a typical obligation attached to such measures. This is probably a good thing, as release measures are granted based on release plans submitted by offenders, whereas safety measures are entirely

82. Court of Cassation, Criminal Chamber, 16 December 2009, no. 09-85.153; 14 April 2010, no. 09-82.291; 12 October 2011, no. 10-88.126.1

83. See ECHR, Berland v. France, Applic. No. 42875/10, 3 September 2015.

84. CC, 21 February 2008, no. 2008-562 DC, spe. § 9; A. Botton, 'A la recherche de la peine perdue en droit constitutionnel', 9 Droit Pénal 7 (2015).

85. The average sentence for rape has consistently oscillated between 8.3 and 8.4 years since 2001 (with the exception of 8.9 in 2010), if life sentences, which, in practice, are only imposed for rape committed in extreme circumstances, are excluded: P.V. Tournier, Observatoire des prisons et autres lieux d'enfermement. Tableau de bord du 1er mai 2013 (2013).

86. O. Razac, 'Les ambiguïtés de l'évolution de l'application des peines à l'aune des "nouvelles mesures de sûreté »', AJ Pénal 397 (2008). My translation.

87. The French legal system is characterised by a great diversity of early release measures: Herzog-Evans (2016), above n. 14 
imposed on offenders, and therefore, raise serious worries in terms of compliance. ${ }^{88}$

Health or mental health law also organises the mandatory commitment of mentally ill persons, whether they are sex offenders or not. Such internment is, since the 2011 Act $^{89}$ on mental health, decided by a judicial criminal judge, the Judge of Liberties and Detention (juge des libertés et de la detention). The 2011 Act followed a decision by the CC which stated that the previous law, pursuant to which an administrative authority, the Prefect, had decisional power, violated the Constitution. ${ }^{90}$ Dangerous people can also be interned in the aforementioned UMD. These structures, which were recently declared constitutional, ${ }^{91}$ focus both on treatment and public safety, although they house the most dangerous of all offenders, often with little hope of significant improvement. A recent study showed that most of those affected are sex offenders. ${ }^{92}$ During Nicolas Sarkozy's presence in the government, six new UMDs were opened, whereas previously there had been only four, all created between 1910 and 1963. Interestingly, whereas human rights activists did campaign quite vociferously against RS, they have been mostly silent concerning UMDs, despite the fact that they host about 550 patients (vs. 5 in RS and for very short periods of time), and the difference between the two is rather blurry; both measures are quite similar in many respects to Dutch TBS. ${ }^{93}$

To sum up, there is a graduation of intervention: less dangerous offenders tend to be dealt with by general criminal or (mental) health rules, whereas the most dangerous or repeat offenders are dealt with by criminal or health (internment in UMD) safety measures.

\section{Evaluation from a Human Rights Perspective}

\subsection{Human Rights Restrictions Intentionally Imposed by Legislators}

Under French law, only legislators are allowed to create or add human rights constraints. Courts can only implement the law and the constitution. Leaving aside the

88. M. Herzog-Evans (ed.), Offender Release and Supervision: The Role of Courts and the Use of Discretion (2015). On the importance of motivation for sex offenders, see P.M. Yates, D. Prescott \& T. Ward, Applying the Good Lives and Self-Regulation Models to Sex Offender Treatment: A Practical Guide for Clinicians (2010).

89. E. Péchillon, 'Les quatre temps du soin sous contrainte: Une loi dont I'application concrète inquiète les professionnels', 32 La lettre des professionnels de santé 8 (2011).

90. CC, 26 November 2010, Applic. No. 2010-71 (QPC)

91. CC, 14 February 2014, Applic. No. 3012-367 (QPC)

92. A. Baratta, J.-L. Senniger \& S. Aroudj, 'Les auteurs de violence sexuelle en unité pour malade difficile', 171 Annales Médico-Psychologiques 513 (2013).

93. M.J.F. van der Wolf and M. Herzog-Evans, 'Mandatory Measures: "Safety Measures". Supervision and Detention of Dangerous Offenders in France and the Netherlands: A Comparative and Human Rights' Perspective', in M. Herzog-Evans (ed.), Offender Release and Supervision: The Role of Courts and the Use of Discretion (2015) 193 highly contentious concept of the 'safety measure' and its main criterion, dangerousness, the constraints that are actually imposed on offenders by most safety measures and SSJ are, as we have seen, quite similar to regular probation, and the courts do not make an excessive use of the obligations that they could impose. A difficulty arises, however, in terms of consent: whereas release and most community sentences are pronounced with the consent of the offender, safety measures are imposed whether they like it or not. Consent is nonetheless not a constitutional or a cardinal principle of criminal law, and its importance can only be stressed on the basis of theoretical ${ }^{94}$ or empirical ${ }^{95}$ arguments.

The detention of dangerous offenders, whether with RS or UMD, raises serious issues in terms of the right to freedom of movement and the right to family contact. It also raises serious issues with regard to the principles of necessity and proportionality. However, it is mostly in view of the principles of the non-retrospectivity of harsher penal laws and of legality that they have been contested.

That being said, as we have seen, the Council of State has ruled that part of the internal regulations of Fresnes were illegal, because they were too similar to prison regulations, particularly in terms of visitation and correspondence, and because they imposed undue limitations on the person's right to a family life. However, these constraints were nowhere near those in place in the Guzzardi case, ${ }^{96}$ a case that has never been mentioned in French jurisprudence ${ }^{97}$ or doctrine, which makes the French ruling rather progressive.

\subsection{European Human Rights and French Safety Measures}

Article 5 has not been utilised in French jurisprudence with the view of safeguarding offenders from RS, although the condemnation of Germany ${ }^{98}$ has raised debates in the French legal doctrine. Most French authors have considered French regulations to be compatible with Article 5, mainly because its procedure offers sufficient guaranties, and because the detention in Fresnes focuses mainly on treatment, rather than confinement. ${ }^{99}$ This statement is highly debatable in view of the decrees that govern it. ${ }^{100}$ Authors have also opined that French RS does not violate Article 5 because it was not sufficiently similar to German Safety

94. M. Herzog-Evans, 'Consent and Probation: An Analogy with Contracts', 7 European Journal of Probation 143 (2015).

95. Herzog-Evans (2015), above n. 88.

96. See ECHR, Guzzardi v. Italy, Applic. No. 7367/76, 3 November 1980.

97. It is important to understand that French courts are not governed by the rule of precedent and are strictly forbidden from expressly referring to cases, whether national or European. This does not mean that a given case cannot influence a French court; however, the court would not be allowed to expressly mention it.

98. See ECHR, M. v. Germany, Applic. No. 19359/04, 17 December 2009

99. J.-P. Céré ‘La rétention de sûreté à l'épreuve de la Convention européenne des droits de l'homme', AJ Pénal 220 (2008); D. Roets, 'La rétention de sûreté à l'aune du droit européen des droits de I'homme', Recueil Dallloz 1840 (2008)

100. M. Herzog-Evans, ‘Les textes d'application de la loi Rétention de sûreté', Recueil Dalloz 3098 (2008) 
Detention. ${ }^{101}$ This statement is equally debatable in view of the direct German - and Dutch ${ }^{102}$ - inspiration for French Safety Detention. ${ }^{103}$

As was mentioned previously, legal disputes have arisen especially with respect to the issue of retrospective laws. However, rather than referring to Article 7 or the rather undemanding Kafkaris ruling, ${ }^{104}$ the courts have referred mostly to Article 8 of the DDH, which is unsurprising, given that most of these disputes have been of a constitutional nature. In all of these cases, a general acceptance of the retrospective nature of harsher penal reforms has prevailed. There is only a very limited exception concerning RS: the Constitutional Council has ruled that it cannot be retrospective when it is pronounced by a criminal sentencing court, but it has not disputed it could be when it is pronounced as a sanction for the violation of $\mathrm{SS} ;{ }^{105}$ this has allowed the internment of five offenders, albeit for very short periods of time (all under two months) in retrospective conditions (they had all committed their offences before 2008).

\section{Conclusion}

There are no less than five safety measures in French criminal law, and a specific sentence (SSJ) that deals with sex offences. Of these five, four comprise mandatory supervision upon release; one consists in additional incarceration. Courts also have several other mental health options (internment in a psychiatric hospital and internment in an UMD) that are available to them. The legal regulations are extremely intricate and complex, which makes it difficult to draw a broad picture of the French legal landscape. At the same time, their sheer complexity, and particularly, their extremely slow pace and cumbersome procedures have contributed to the overall very modest use of safety measures, notably the most constraining ones. The courts have been extremely prudent in their use of safety measures, and this has a lot to do with the judiciary's professional culture, which comprises both a strong belief in criminal law principles and a belief in rehabilitation, ${ }^{106}$ along with a considerable lack of material and human resources. For this reason, in practice, most sex offenders are still processed through general criminal law procedures and rules, whether they are custodial and community sentences or various early release measures with supervision.

101. J. Leblois-Happe, 'Rétention de sûreté vs Unterbringung in die Sicherungsverwahrung: les enseignements d'une comparaison franco-allemande', AJ Pénal 209 (2008); C.A. Kupferberd, 'Sicherungsverwahrung ou la rétention de sûreté allemande', Dr. pénal 8 (2008).

102. As a report by two senators reveals: Ph. Goujon and Ch. Gautier, Les délinquants dangereux atteints de troubles psychiatriques, 420 Rapp. Sénat (2006).

103. J. Leblois-Happe, above n. 101; C. A. Kupferberd, above n. 101.

104. See ECHR, Kafkaris v. Cyprus, Applic. No. 21906/04, 12 December 2008.

105. CC, 21 févr. 2008, no. 2008-562 DC.

106. M. Herzog-Evans (2014), above n. 42.
Moreover, in terms of the constraints imposed on offenders, except for RS and PSEM, the supervision imposed in the context of safety measures and SSJ is virtually identical to regular probation. The difference between mandatory safety supervision and regular probation is also becoming more blurry, as parole can now be linked to PSEM and prolonged by SS, and can be perpetual in the case of lifers. However, safety measures have had a detrimental impact on early release measures such as parole. Courts can now safely deny sex offenders' parole, a measure for which they would be blamed if a new offence was committed, but then impose mandatory supervision, when the offender has served his/her entire sentence. If parole and safety measures' supervision is virtually identical, a significant difference is that parole is applied for by the prisoner, who has to work on his/her own release plan. Safety measures' on the other hand, are imposed upon him. It is therefore doubtful that the same level of 'substantive compliance'107 and adherence to the measure is achieved in both cases.

That being said, the absence of financial and human resources prevents both legislators and the courts from imposing very constraining measures, and the lack of a collaborative culture and EBP awareness means that such policies have little chance of making a difference. In spite of the punitive discourse that gained momentum during the Sarkozy era, in reality, sex offenders still enjoy most of their rights, including the right to become inebriated and to fully access the Internet. For the most part, 'safety' is brandished as a mere gimmick for political purposes, but is not realised in practice. Inevitably, then, high-profile cases regularly awaken France from its daze, just long enough for it to pass new laws, before it falls back into the arms of Morpheus.

107. G. Robinson and F. McNeill, 'Exploring the Dynamics of Compliance with Community Penalties', 12 Theoretical Criminology 431 (2008). 